\title{
Attenuation of Acute Morphine Withdrawal in the Neonatal Rat by the Competitive NMDA Receptor Antagonist LY235959
}

Kathy L. Jones, Ph.D., Hongbo Zhu, M.S., Shirzad Jenab, Ph.D., Ted Du, B.S., Charles E. Inturrisi, Ph.D., and Gordon A. Barr, Ph.D.

The present study examined the ability of LY235959, a competitive $N$-methyl-D-aspartate (NMDA) receptor antagonist, to attenuate behaviors and c-fos $m R N A$ expression associated with acute morphine withdrawal in the infant rat. Rat pups were given a single dose of morphine (10.0 mg/kg, s.c.) or saline. Two hours later, pups were removed from the dam and injected with either LY235959 (10.0 mg/kg, s.c.) or saline. Fifteen minutes later acute morphine withdrawal was precipitated with naltrexone $(10.0 \mathrm{mg} / \mathrm{kg}$, s.c.) and behaviors were recorded every $15 \mathrm{~s}$ for the next $60 \mathrm{~min}$. Immediately after behavioral testing, brain and spinal cord were assayed for c-fos $m R N A$ analysis by solution hybridization. The intensity of the morphine withdrawal syndrome was reduced in pups pretreated with LY235959. Withdrawal behaviors such as head moves, moving paws, rolling, and walking were decreased, and vocalizations were completely eliminated in pups pretreated with LY2359559. Acute morphine withdrawal increased c-fos $m R N A$ expression in the brain and the spinal cord, which was attenuated by pre-treatment of LY235959. Thus, in the 7-day-old rat, as in the adult, $N M D A$ receptors play a role in the behavioral and molecular manifestations of acute morphine withdrawal.

[Neuropsychopharmacology 26:301-310, 2002]

(C) 2002 American College of Neuropsychopharmacology. Published by Elsevier Science Inc.
KEY WORDS: c-Fos mRNA; Opiate withdrawal; Neonatal rat; Solution hybridization; LY235959; NMDA receptor antagonist; Ontogeny; Glutamate

In humans, exposure to opiates for either medical or nonmedical reasons leads to dramatic behavioral and neural changes resulting in physical dependence

From the Department of Pharmacology, Weill Medical College of Cornell University, New York, NY (KLJ, SJ, TD, CEI), Biopsychology Doctoral Program, Hunter College, City University of New York, 695 Park Ave., New York, NY (KLJ, HZ, GAB), and New York State Psychiatric Institute, 1051 Riverside Drive, New York, NY (GAB)

Address correspondence to: Gordon A. Barr, Department of Psychology, Hunter College, City University of New York 695 Park Avenue, New York, NY 10021, Tel.: (212) 772-5610, Fax: (212) 7724477, E-mail: gbarr@hunter.cuny.edu

Received March 23, 2001; revised June 26, 2001; accepted July 30, 2001.

Online publication: $8 / 6 / 01$ at www.acnp.org/citations/ Npp080601160
(Trujillo and Akil 1991b). Although physical dependence is classically thought to develop after chronic exposure to opiates (chronic opiate dependence), the adaptational changes underlying physical dependence begin with the first exposure to an opiate (Heishman et al. 1989a,b; Kirby et al. 1990). Thus, acute opiate withdrawal refers to the withdrawal syndrome precipitated by administration of an opioid antagonist after either a single dose or a short-term infusion of opioid agonist (Martin and Eades 1964; Bickel et al. 1988).

Despite decades of research, our understanding of the mechanisms underlying opiate physical dependence and withdrawal is still very limited (Mayer et al. 1999; Trujillo 1999) and multiple mechanisms may operate in these processes (Thorat et al. 1994). There is increasing evidence indicating that N-methyl-D-aspartate (NMDA) receptor antagonists inhibit the development of $m u$ receptor mediated opiate dependence in the adult 
rodent, and that the NMDA receptor and its second messenger systems play pivotal roles in opiate tolerance, dependence and withdrawal (Trujillo and Akil 1991a; Inturrisi 1997; Mao 1999; Mayer et al. 1999).

It is not known whether these mechanisms in adults apply to infants. On the one hand, opiate dependence can be established in fetuses or infant rat pups if the dams are exposed to opiates during their pregnancy or the pups are treated directly with opiates (Jones and Barr 1995, 2000; Windh et al. 1995; Thornton et al. 1997; Barr et al. 1998). On the other hand, the neonatal CNS is both structurally and functionally different from that of the adult, and significant changes in opioid actions occur both prenatally and postnatally (Barr 1992, 1993; Fitzgerald 1995; Marsh et al. 1997; Fitzgerald and Jennings 1999). More importantly, the NMDA receptor, which is believed to play a crucial role in the establishment of opiate dependence, undergoes qualitative and quantitative changes during development (Kalb et al. 1992; Hori and Kanda 1994; Kalb and Fox 1997). These include significant developmental alterations both in the density of the receptor (Tremblay et al. 1988; Morin et al. 1989; Represa et al. 1989), the sensitivity of the receptor complex to magnesium (Ben-Ari et al. 1988; Bowe and Nadler 1990; Morrisett et al. 1990), and the rise and decay times of the NMDA receptor-mediated excitatory post-synaptic currents (EPSCs) (Akaike and Rhee 1997; Bardoni et al. 1998). Recently, due to the advancement in cloning technology and gene knockout technology, the molecular structure of the NMDA receptor complex has been characterized (Ozawa et al. 1998; Dingledine et al. 1999). The accumulating evidence indicates that the various subunits (NR1, NR2A$\mathrm{D}, \mathrm{NR} 3 \mathrm{~A}$ ) composing the native NMDA receptor channel undergo dramatic differential change during the first few weeks of the postnatal life in the rat (Dingledine et al. 1999). It has been suggested that the NMDA receptor is not present in fully mature form until the second postnatal week in the rat (Sircar 2000). Thus, the pharmacological effects of NMDA antagonism in the infant may not necessarily be comparable to those in the adult. In fact, the acute or chronic administration of NMDA receptor antagonists is ineffective in suppressing the expression of the behavioral signs of withdrawal from chronic morphine treatment followed by naltrexone challenge, in the 4 to 7-day-old rat (Bell and Beglan 1995; Zhu and Barr 2000, 2001), which is in contrast to reports in the adult (Trujillo and Akil 1991a).

Although several laboratories, including ours, have examined the behavioral, biochemical and pharmacological aspects of opiate withdrawal induced by chronic opiate administration in the infant animals (Jones and Barr 1995, 2000; Windh et al. 1995; Thornton and Smith 1997; Thornton et al. 1997; Ceger and Kuhn 2000; Zhu and Barr 2000, 2001), little is known about the acute morphine withdrawal syndrome in the infant animal model (Ceger and Kuhn 2000). Thus, the present study investigated the behavioral and biochemical parameters of acute morphine withdrawal in the 7-day-old rat. In addition, since NMDA receptor antagonists were reported to inhibit both behaviors (Herman et al. 1995) and c-fos expression (Rasmussen et al. 1995) associated with opiate withdrawal, we also examined the pharmacological effect of the pre-treatment of the NMDA receptor antagonist, LY235959 on the acute withdrawal behavior and withdrawal associated $c$-fos expression.

\section{MATERIALS AND METHODS}

\section{Animals}

All animal procedures were in accordance with the "Principles of laboratory animal care" (NIH publication 1996) and approved by the institutional animal care and use committee at Weill Medical College of Cornell University. The subjects were the offspring of Sprague-Dawley rats. Pregnant dams were purchased on gestational day 19 or 20 (Charles River). Dams were individually housed in plastic tubs with wood chips in a colony room maintained at $22-24^{\circ} \mathrm{C}$ on a 12 -h light/12-h dark photocycle with light onset at 7 A.M. The breeding colony existed in a separate room with minimal disturbances except for normal cleaning, feeding and record keeping. Dams had Purina Lab Chow (Purina 5012) and water available ad libitum. Pups were termed 0 days of age upon birth. After parturition, litters were culled to six male pups. Pups were tattooed with India ink (Geller and Geller 1966), which was injected into one or two paws to label permanently individual pups in each litter.

\section{Drug Treatment and Behavior Testing}

Morphine sulfate was obtained from the National Institute on Drug Abuse (Rockville, MD). Naltrexone and NMDA was purchased from Sigma Chemical (St. Louis, MO). LY235959 was obtained from Eli Lilly and Company (Indianapolis, IN).

In the afternoon of the seventh day, animals were transported from the animal facility to our laboratory in plastic tubs with wood chip bedding and placed in an observation chamber maintained at approximately $33^{\circ} \mathrm{C}$. Pups were weighed and assigned to one of four treatment groups ( $\mathrm{n}=25$ for each group). Two groups received $10 \mathrm{mg} / \mathrm{kg}$ morphine (s.c.) and two groups received saline injection. Two hours later pups were injected with either LY235959 (10.0 mg/kg, s.c.) or saline. The order of treatment conditions was assigned randomly within each experiment. After the drug treatment, the pup was then placed back into the observation chamber with the remainder of the litter (without the dam). Fifteen minutes later, naltrexone $(10.0 \mathrm{mg} /$ $\mathrm{kg}$, s.c.) was injected to precipitate withdrawal. The be- 
havior of the pups was then observed for $60 \mathrm{~min}$ after the injection of naltrexone. Every $15 \mathrm{~s}$, the behavior of the pups was identified and recorded on a checklist (see Table 1 for definitions of behavior included in the checklist) by an observer who was blind to the drug and dose. The next pup was then tested until all treatment groups were completed.

High doses of NMDA receptor antagonists are reported to have motor effects on the rat (Trujillo and Akil 1995). Unfortunately, all of the data are from the adult and there is a lack of data in the pharmacological effect of these compounds in the infant rat. Thus, in order to determine a suitable dose of LY235959 for our morphine withdrawal test, a separate group of rats ( $\mathrm{n}=$ 15) was tested for motor behavior impairment. Cumulative doses $(0,1.0,4.0,14.0,34.0$ and $60.0 \mathrm{mg} / \mathrm{kg}$, increasing every $15 \mathrm{~min}$ ) of LY235959 were tested for their motor impairment liability using the $30^{\circ}$ incline test, grasping and righting reflex. In the $30^{\circ}$ incline test, pups were placed facing downward on a screen positioned at a $30^{\circ}$ angle and allowed to position themselves upright. In the grasping test, the forepaws of the pup were placed on a rod and tested for their ability to grasp. In the righting test, pups were placed on their back and observed for their ability to return to the upright position. Pups were scored on a scale from 0 to 2 : with 0 indicating no motor impairment, 1 indicating slight motor impairment and 2 indicating severe motor impairment. Specifically, in all three tests, each pup was given five trials for any specific drug dose, if the pup successfully completed four or five trials, it was scored as 0 . If the pup completed two or three trials, it was scored as 1 . If the pup completed fewer than two trials, it was scored as 2 . In addition, using the same paradigm, we tested a separate group of rats $(n=8)$ for motor behavior impairment at the specific dose of LY235959 $(10 \mathrm{mg} / \mathrm{kg})$ and with a similar time course (up to 75 min post injection of LY235959) as we employed in the morphine withdrawal experiment.

To determine the effectiveness of the dose of LY235959 $(10 \mathrm{mg} / \mathrm{kg})$ in inhibiting NMDA receptor re-

Table 1. Behavioral Definitions

\begin{tabular}{ll}
\hline Behavior & \multicolumn{1}{c}{ Definition } \\
\hline Head Moves & $\begin{array}{c}\text { Lateral and rotary motions of the head } \\
\text { Continuous movement of the } \\
\text { hindpaws without walking } \\
\text { Sedated appearance with no } \\
\text { movement } \\
\text { Turning the body over at least one } \\
\text { full rotation } \\
\text { Emitting an audible sound } \\
\text { Talling }\end{array}$ \\
Vocalizations & $\begin{array}{c}\text { Placing at least two forepaws on the } \\
\text { wall of the observation chamber }\end{array}$ \\
Walking &
\end{tabular}

lated $c$-fos expression, in a separate experiment, rats were pre-treated either with LY2359559 $(10 \mathrm{mg} / \mathrm{kg}$, s.c.) or saline ( $\mathrm{n}=5$ for each group). Then $15 \mathrm{~min}$ later, half of the LY235959 pre-treated and half of the saline pre-treated pups were treated with NMDA ( $20 \mathrm{mg} / \mathrm{kg}$, i.p.); the remaining pups in each pre-treatment group were treated with saline. In this experiment, $c$-fos mRNA expression was measured and no behavior tests were involved.

\section{Tissue Collection and RNA Extraction}

Immediately after withdrawal behavior testing, animals were sacrificed by decapitation. Since $c$-fos mRNA production typically peaks approximately 15-45 min following a behavioral event (Zhu and Inturrisi 1993), the $1 \mathrm{~h}$ exposure of the rats to morphine withdrawal helped to insure a representative sampling of the withdrawal period.

Following $\mathrm{CO}_{2}$ narcosis and decapitation, the brain (minus cerebellum) and spinal cord were removed. Each tissue was immediately homogenized and the RNA recovered using the Trizol reagent (Life Sciences, Gaithersburg, MD). Each value represents the mean of five RNA extracts for each tissue $(n=5)$.

\section{Solution Hybridization for $c$-fos mRNA}

c-Fos mRNA levels were determined in tissue extracts of total cellular RNA using a previously described solution hybridization assay for $c$-fos mRNA (Zhu et al. 1993). A ${ }^{32} \mathrm{P}$-labeled antisense riboprobe was prepared by in vitro transcription. The plasmid for the rat $c-f o s$ riboprobe contained a 970 bp BglII-ScaI fragment (Zhu et al. 1993) obtained from a full length cDNA (Curran et al. 1987). $c$-Fos riboprobe transcripts (specific activity $=6.5 \times 10^{8}$ $\mathrm{dpm} / \mu \mathrm{g}$ ) were applied to a CF11 column (Zhu et al. 1992, 1993), washed to remove unincorporated label, and eluted with TSE: ethanol 78:22 (v/v) (TSE is 0.05 M Tris- $\mathrm{HCl}, 0.1 \mathrm{M}$ sodium chloride and 0.001 M EDAT, $\mathrm{pH}$ 7.0) to obtain a single stranded ribprobe fraction free of "snap back regions" which contribute to background in the solution hybridization assay (Zhu et al. 1992). Nonradiolabeled mRNA "sense" standards were prepared by in vitro transcription (Zhu et al. 1992) using the full length cDNA described above (Curran et al. 1987).

Total cellular RNA was determined by UV absorbency at $260 \mathrm{~nm}$. Duplicate aliquots of each RNA sample were dried under a vacuum in $1.5 \mathrm{ml}$ eppendorf tubes and then resuspended in $30 \mu \mathrm{g}$ of hybridization buffer (10 mM N-tris [hydroxymethyl]methyl-2-aminoethanesulfonic acid, $10 \mathrm{mM}$ EDTA, $0.3 \mathrm{M} \mathrm{NaCl}, 0.5 \%$ SDS and pH 7.4) that also contained $150,000 \mathrm{dpm}$ of riboprobe. Samples were covered with two drops of mineral oil and hybridized at $75^{\circ} \mathrm{C}$ for $4 \mathrm{~h}$. After hybridization, $300 \mu \mathrm{l}$ solution containing a high salt buffer $(0.3 \mathrm{M}$ $\mathrm{NaCl}, 5 \mathrm{mM}$ EDTA, and $10 \mathrm{mM}$ Tris- $\mathrm{HCl}, \mathrm{pH}$ 7.5), 40 
$\mu \mathrm{g} / \mathrm{ml}$ RNase A (Worthington Biochemicals, Freehold, N.J.), and $2 \mu \mathrm{g} / \mathrm{ml}$ RNase T1 (Calbiochem, San Diego, CA) was added and samples were incubated at $30^{\circ} \mathrm{C}$ for $1 \mathrm{~h}$ to digest unhybridized probe. The ribonuclease reaction was terminated with $1 \mathrm{ml}$ of $5 \%$ trichloroacetic acid (TCA) and $0.75 \%$ sodium pyrophosphate. One drop of $0.5 \%$ BSA was added to aid precipitation. This solution was mixed and the TCA precipitable dpms were collected onto glass microfiber filter paper (Reeves Angel 934AH, Brandel, Gaithersburg, MD) using a 24 place cell harvester (Brandel, Gaithersburg, MD). The filter was washed three times with 5\% TCA, dried under an infra-red light and counted by liquid scintillation in $5 \mathrm{ml}$ hydrofluor scintillation solution (National Diagnostics, Manville, NJ).

The standard calibration curve for $c$-fos mRNA is linear from 1.95 to $250 \mathrm{pg}$ of the full length $c$-fos sense transcript (i.e., $c$-fos mRNA) with a correlation coefficient of 0.997 . In ten consecutive experiments the interassay coefficient of variation averaged $7.4 \%$ and the intra-assay coefficient of variation average $3.8 \%$ for duplicate aliquots of 30 different extracts.

\section{Statistics}

Withdrawal was analyzed by separate 1-way analysis of variance (ANOVA) for each withdrawal behavior followed by the Student-Newman-Keuls test for multiple comparison tests at the 0.05 level of significance.

All $c$-fos mRNA expression data points from the brain and spinal cord were analyzed with a 1-way ANOVA with subsequent group comparisons made using the Student-Newman-Keuls test at the 0.05 level of significance.

\section{RESULTS}

\section{Withdrawal Behaviors}

A single dose of morphine $(10 \mathrm{mg} / \mathrm{kg}$, s.c.) two hours later followed by a single injection of naltrexone (10 $\mathrm{mg} / \mathrm{kg}$, s.c.) induced a plethora of acute morphine withdrawal behaviors in the 7-day-old rat (see Figure 1). Compared with the saline control group, the morphine treated animals displayed significantly increased withdrawal behaviors and decreased quiet behavior. The increased withdrawal behaviors included head moves, moving paws, rolling, vocalizations, walking and wall climbing. The categories and intensity of these acute withdrawal behaviors are generally comparable to those seen in withdrawal after chronic morphine administration (Jones and Barr 1995).

The dose of LY235959 to cause a minimal motor function impairment in the 7-day-old rat we tested was 14 $\mathrm{mg} / \mathrm{kg}$ as determined by the cumulative dosing experiment (see Table 2). Pre-treatment with the competitive NMDA receptor antagonist LY235959 at $10 \mathrm{mg} / \mathrm{kg}$, a dose that did not cause any motor function impairment by itself (see Table 3), significantly reduced acute morphine withdrawal behaviors in the 7-day-old rat (see Figure 1). Compared with the control group that received morphine but no LY235959 prior to naltrexone challenge, all withdrawal behaviors in the LY235959 pre-treated pups were significantly attenuated and quiet behavior significantly increased. Withdrawal behaviors attenuated by pre-treatment of LY2359559 included head moves, moving paws, rolling, vocalization, walking and wall climbing. In contrast, pre-treatment of $10 \mathrm{mg} / \mathrm{kg}$ LY235959 did not significantly change the occurrences of these behaviors in rats that did not receive morphine treatment, indicating that LY235959's effect in attenuating these behaviors is specific to acute morphine withdrawal rather than to any non-specific effect of this compound.

\section{Opiate Withdrawal Evoked Brain $c$-fos mRNA Expression}

In the 7-day-old rat, brain c-fos mRNA expression was significantly elevated to approximately $300 \%$ of the control during acute morphine withdrawal. This acute morphine withdrawal-induced $c$-fos mRNA expression was significantly attenuated by the pre-treatment of LY235959 $15 \mathrm{~min}$ prior to naltrexone injection (see Figure 2, upper panel). There are two important observations here: (1) This attenuation was specific to the acute morphine withdrawal syndrome, since LY2359559 alone did not significantly alter the expression of $c$-fos mRNA in the brain (see Figure 2, upper panel). (2) Although pre-treatment of LY235959 significantly attenuated acute morphine withdrawal induced $c-f o s$ mRNA expression, $c$-fos mRNA expression did not return completely to baseline. Indeed, even though the dose of LY235959 (10 mg/kg) completely blocked NMDA induced c-fos mRNA expression in the brain (see Figure 2, lower panel), it attenuated the acute morphine withdrawal evoked increase of $c$-fos mRNA expression by less than 50\% (see Figure 2, lower panel).

\section{Opiate Withdrawal Evoked Spinal Cord $c$-fos mRNA Expression}

Similar to that in the brain, spinal cord c-fos mRNA expression was also significantly elevated during acute morphine withdrawal and this elevation was attenuated by the pre-treatment with LY235959 (see Figure 2, middle panel). The attenuation is specific to the acute morphine withdrawal syndrome, since LY235959 alone did not significantly alter the expression of $c$-fos mRNA in the spinal cord (see Figure 2, middle panel). Again, pre-treatment of LY235959 did not completely block (less than $50 \%$ ) the elevation of $c$-fos mRNA expression evoked by acute morphine withdrawal (see Figure 2, middle panel). 

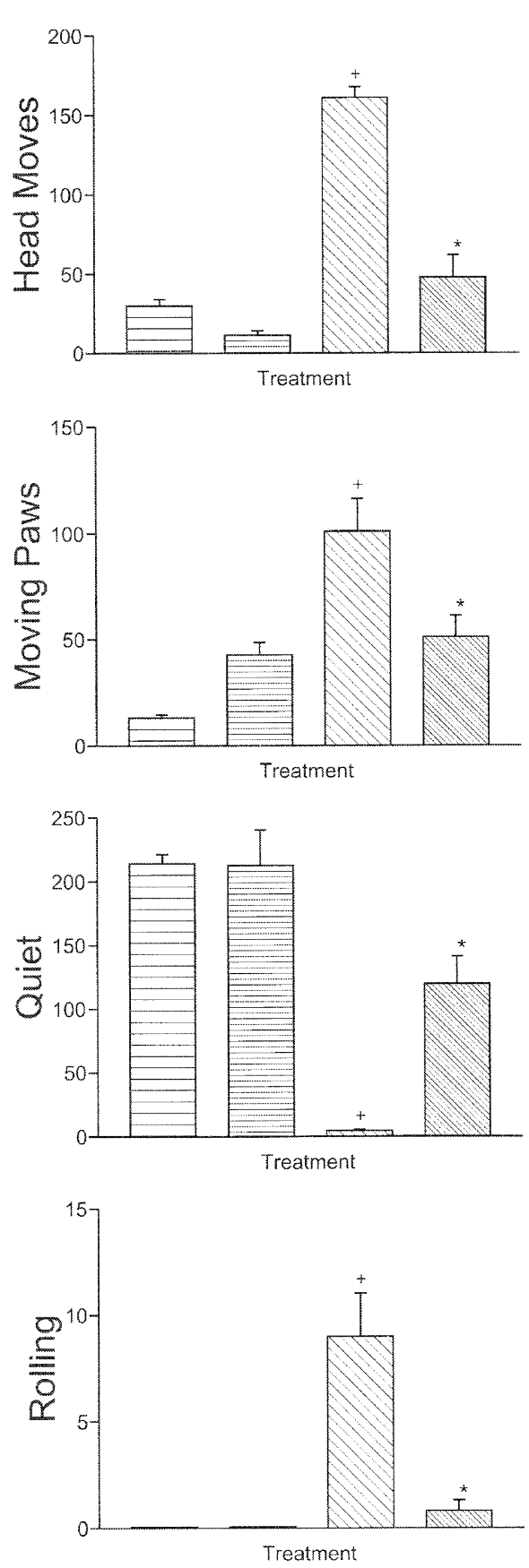

Saline + Saline

Saline + LY235959

Morphine + Saline

Morphine + LY235959
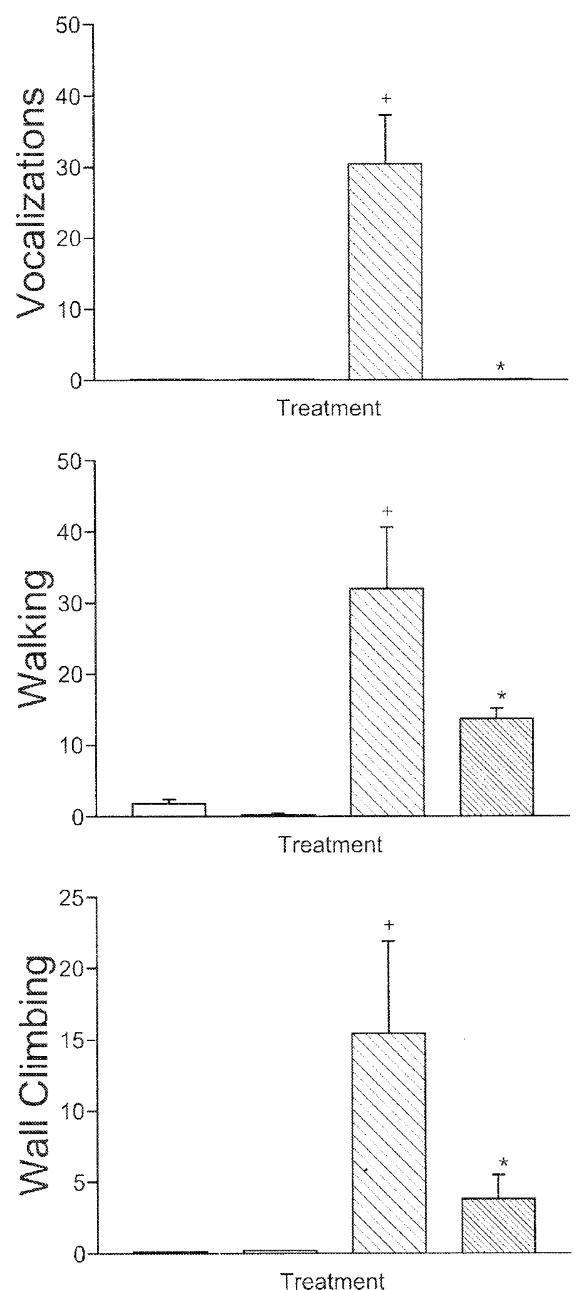

Figure 1. The effect of pretreatment with the competitive NMDA receptor antagonist LY235959 (10 $\mathrm{mg} / \mathrm{kg})$ on naltrexone-precipitated acute morphine withdrawal behaviors in the 7-day-old rat. Ordinate: Mean occurrences (Mean \pm one S.E.M.) in 60 min of opiate withdrawal behaviors (definition see Table 1). Abscissa: treatment conditions. Withdrawal was precipitated by naltrexone $(10 \mathrm{mg} / \mathrm{kg})$ in all groups. ${ }^{+} p<$ .05 compared with the saline plus saline control group. ${ }^{*} p<$ .05 compared with the morphine plus saline group. For all tested behaviors, no significant results were found between the two groups that did not receive morphine injection.
Pre-treatment of $10 \mathrm{mg} / \mathrm{kg}$ LY235959 did not significantly alter the expression of $c$-fos mRNA in either the brain or the spinal cord in 7-day-old rats that did not receive morphine treatment, suggesting that LY235959's suppression of $c-f o s$ mRNA expression is restricted to acute morphine withdrawal.

\section{DISCUSSION}

There are three major conclusions from the present study: (1) As manifested by both behavioral and mo- lecular measures, acute morphine dependence can be induced by a single injection of morphine in the rat as young as 7 days of age. (2) Acute morphine withdrawal in the 7-day-old rat was attenuated by pretreatment of a competitive NMDA receptor antagonist LY235959. (3) Although the dose of LY235959 was sufficient to have completely blocked NMDA receptor related neural transmission, its inhibition of acute morphine withdrawal was not complete. We explore the implications for each of these three observations. 
Table 2. Behavioral Toxicity of LY235959 Using the Cumulative Dose Protocol. Pups Were Treated s.c. with LY2359595 and Tested for Motor Impairment Using the $30^{\circ}$ Incline Test, Grasping and Righting Reflex $(\mathrm{n}=15)$

\begin{tabular}{|c|c|c|c|c|}
\hline \multirow{2}{*}{$\begin{array}{l}\text { Cumulative Dose } \\
(\mathrm{mg} / \mathrm{kg})\end{array}$} & \multirow{2}{*}{$\begin{array}{l}\text { Timing (minutes after } \\
\text { first injection) }\end{array}$} & \multicolumn{3}{|c|}{ Tests } \\
\hline & & $30^{\circ}$ Incline & Grasping & Righting \\
\hline 0 & 0 & 0 & 0 & 0 \\
\hline 1.0 & 15 & 0 & 0 & 0 \\
\hline 4.0 & 30 & 0 & 0 & 0 \\
\hline 14.0 & 45 & 1 & 1 & 1 \\
\hline 34.0 & 60 & 2 & 2 & 2 \\
\hline 60.0 & 75 & 2 & 2 & 2 \\
\hline
\end{tabular}

Note: Three tests were used to evaluate motor impairment produced by LY235959

1. The $30^{\circ}$ incline test. Pups were placed facing downward on a screen positioned at $30^{\circ}$ angle and allowed to position themselves upright.

2. Grasping. The forepaws of the pup were placed on a rod and tested for their ability to grasp.

3. Righting. Pups were placed on their back and observed for their ability to return to the upright position.

Pups were scored on a scale from 0 to 2 :

$0=$ no motor impairment

$1=$ slight motor impairment

2 = severe motor impairment

The dose was increased every 15 minutes and each of the 15 pups showed the level of impairment indicated above.

\section{Acute Opiate Withdrawal Exists in Infant}

Using the 7-day-old rat as a model, the present study has confirmed that opiate dependence can be observed after a single dose of morphine. At this age, $2 \mathrm{~h}$ after morphine injection, a myriad of withdrawal behaviors was precipitated by naltrexone challenge. In addition, c-fos mRNA expression levels were significantly increased in both the brain and the spinal cord. Thus, as in the adult rat, acute opiate withdrawal exists in the infant rat. Our results are consistent with the only other available report on acute opiate withdrawal in the infant rat (Ceger and Kuhn 2000) and we extended the findings of that study by demonstrating that, in addition to withdrawal behaviors, molecular indices such as $c$-fos mRNA expressions are also increased.

\section{The NMDA Receptor Antagonist LY235959 Is Effective in Suppressing Acute Opiate Withdrawal}

The existing literature on whether various NMDA receptor antagonists can inhibit the expression of opiate

Table 3. Behavioral Toxicity of $10 \mathrm{mg} / \mathrm{kg}$ LY235959 over 75-Min Period. Pups Were Treated s.c. with 10 mg/kg LY2359595 And Tested for Motor Impairment Using The $30^{\circ}$ Incline Test, Grasping and Righting Reflex $(\mathrm{n}=8)$

\begin{tabular}{|c|c|c|c|c|c|c|c|c|c|}
\hline \multirow{3}{*}{$\begin{array}{l}\text { Minutes after } 10 \mathrm{mg} / \mathrm{kg} \\
\text { LY235959 injection }\end{array}$} & \multicolumn{9}{|c|}{ Rats showing each level of motor impairment } \\
\hline & \multicolumn{3}{|c|}{$30^{\circ}$ Incline Score } & \multicolumn{3}{|c|}{ Grasping Score } & \multicolumn{3}{|c|}{ Righting Score } \\
\hline & 0 & 1 & 2 & $\mathbf{0}$ & 1 & 2 & $\mathbf{0}$ & 1 & 2 \\
\hline $0^{*}$ & 8 & 0 & 0 & 8 & 0 & 0 & 8 & 0 & 0 \\
\hline 15 & 8 & 0 & 0 & 8 & 0 & 0 & 8 & 0 & 0 \\
\hline 30 & 8 & 0 & 0 & 8 & 0 & 0 & 8 & 0 & 0 \\
\hline 45 & 8 & 0 & 0 & 8 & 0 & 0 & 8 & 0 & 0 \\
\hline 60 & 8 & 0 & 0 & 7 & 1 & 0 & 8 & 0 & 0 \\
\hline 75 & 8 & 0 & 0 & 7 & 1 & 0 & 8 & 0 & 0 \\
\hline
\end{tabular}

Note: Three tests were used to evaluate motor impairment produced by $10 \mathrm{mg} / \mathrm{kg}$ LY235959 (s.c.)

1. The $30^{\circ}$ incline test. Pups were placed facing downward on a screen positioned at $30^{\circ}$ angle and allowed to position themselves upright.

2. Grasping. The forepaws of the pup were placed on a rod and tested for their ability to grasp.

3. Righting. Pups were placed on their back and observed for their ability to return to the upright position.

Pups were scored on a scale from 0 to 2

$0=$ no motor impairment

$1=$ slight motor impairment

2 = severe motor impairment

Each cell represents the number of rats (out of a total of 8 subjects) that earned the specific score. No significant results were found for the time effect.

${ }^{*}$ :Immediately before LY235959 treatment. 


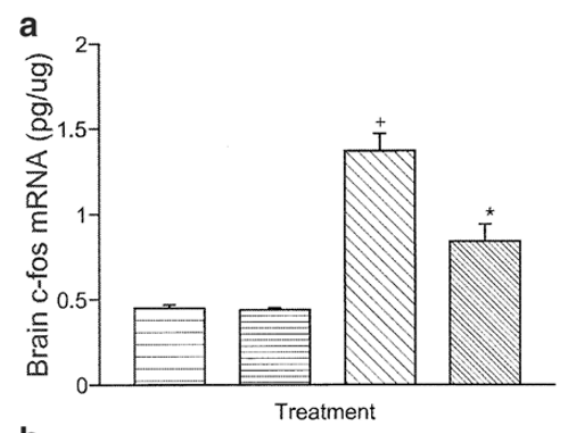

b
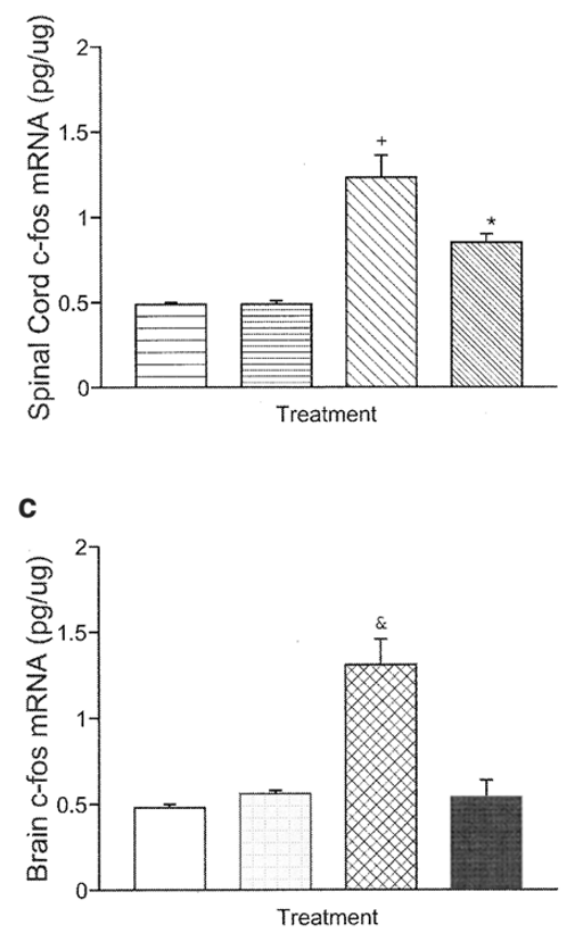

Saline + Saline

Saline + LY235959

Morphine + Saline

Morphine + LY235959

Saline + Saline

Saline + LY235959

Morphine + Saline

Morphine + LY235959
Saline + Saline

LY235959 + Saline

Saline + NMDA

LY235959 + NMDA

Figure 2. Upper panel: The effect of pre-treatment with the competitive NMDA receptor antagonist LY235959 (10 mg/kg) on brain $c$-fos mRNA expression evoked by naltrexone-precipitated acute morphine withdrawal in the 7-day-old rat. Ordinate: Mean $c$-fos mRNA expression (pg/ $\mu \mathrm{g}$ ) in the brain (Mean \pm one S.E.M.). Abscissa: treatment conditions. Withdrawal was precipitated by naltrexone $(10 \mathrm{mg} / \mathrm{kg})$ in all groups. ${ }^{+} p<.05$ compared with the saline plus saline control group. ${ }^{*} p<$ .05 compared with the morphine plus saline group. No significant results were found between the two groups that did not receive morphine injection. Middle panel: The effect of pre-treatment with the competitive NMDA receptor antagonist LY235959 (10 mg/kg) on spinal cord c-fos mRNA expression evoked by naltrexone-precipitated acute morphine withdrawal in the 7-day-old rat. Ordinate: Mean $c$-fos mRNA expression (pg/ $\mu \mathrm{g})$ in the spinal cord (Mean \pm one S.E.M.). Abscissa: treatment conditions. Withdrawal was precipitated by naltrexone $(10 \mathrm{mg} / \mathrm{kg})$ in all groups. ${ }^{+} p<.05$ compared with the saline plus saline control group. ${ }^{*} p<.05$ compared with the morphine plus saline group. No significant results were found between the two groups that did not receive morphine injection. Lower panel: The effect of LY235959 in inhibiting NMDA receptor responsible neural activity as assessed by NMDA-evoked c-fos expression in the 7-day-old rat's brain. Ordinate: Mean $c$-fos mRNA expression (pg/ $\mu \mathrm{g}$ ) in the brain (Mean \pm one S.E.M.). Abscissa: treatment conditions. \& $p<.05$ compared with the saline plus saline control group. No significant results were found among the two groups that did not receive morphine and the group that received LY235959 (10 mg/kg) $15 \mathrm{~min}$ prior to NMDA challenge.

withdrawal is not consistent (Herman et al. 1995; Trujillo and Akil 1995). Although most laboratories report that NMDA antagonists inhibit withdrawal symptoms (Tanganelli et al. 1991; Brent and Chahl 1993; Cappendijk et al. 1993); others report that they do not
(Trujillo and Akil 1991a,b), and still others report mixed results (Rasmussen et al. 1991; Thorat et al. 1994). Two additional factors make comparison between our data with any available literature difficult. First, most of these studies were done in the adult rat or mouse and 
there are significant developmental differences in the effectiveness of NMDA receptor blockers to attenuate withdrawal (Zhu and Barr 2000, 2001). Second, in all the studies investigating the pharmacology of various NMDA receptor antagonists on opiate withdrawal in infant animals, the chronic morphine administration paradigm was adopted (Bell and Beglan 1995; Zhu and Barr 2000, 2001). Thus, as far as we know, the present study represents the first report of the pharmacology of a NMDA receptor antagonist on acute opiate withdrawal in rat as young as 7 days old.

Earlier behavioral studies suggest that acute and chronic opiate withdrawal are quantitatively different. For example, the withdrawal syndrome resulting from chronic dependence tends to be more intense and of longer duration than that from acute dependence (Martin and Eades 1964). On the other hand, the observed signs and symptoms are qualitatively similar (Martin and Eades 1964). This qualitative similarity in withdrawal symptoms after acute and chronic opiate exposure suggests that the same mechanisms may underlie both processes (Heishman et al. 1989b). More recent molecular studies, however, suggest that the mechanisms underlying acute and chronic actions of opiates may be qualitatively different from, and in some cases opposing to, each other (Sharma et al. 1975; Nestler and Aghajanian 1997). Notably, acute morphine inhibits adenylate cyclase and results in a reduction of cAMP production in the cell whereas repeated treatment of morphine increases adenylate cyclase and cAMPdependent protein kinase (Duman et al. 1988; Nestler and Tallman 1988; Nestler and Aghajanian 1997).

Interestingly, the acute morphine withdrawal behavioral repertoire of the 7-day-old rat characterized in the present study is qualitatively comparable of that documented in reports using the chronic morphine injection paradigm (Jones and Barr 1995; Windh et al. 1995; Thornton et al. 1997). Withdrawal behaviors representative of the acute morphine injection paradigm generally coincide with withdrawal behaviors typical of the chronic morphine administration model. For example, withdrawal behaviors such as head moves, moving paws, rolling, walking, wall climbing and vocalizations are typical of both withdrawal paradigms. However, our data do not support the hypothesis that the same mechanisms underlie both acute and chronic opiate dependence. Previously, our laboratory and others reported that neither competitive nor non-competitive NMDA receptor antagonists were effective in suppressing opiate withdrawal in the chronic morphine treatment paradigm in infant rats (Bell and Beglan 1995; Zhu and Barr 2000, 2001). Thus, it is possible that although behavioral indices of acute and chronic morphine withdrawal are similar, the underlying mechanisms differ. The differential short-term and long-term molecular changes (e.g. cAMP levels) resulting from acute and chronic morphine treatment may account for the observed difference in the pharmacology of NMDA receptor antagonists in chronic and acute morphine withdrawal paradigms.

\section{Expression of Acute Opiate Withdrawal Involves Multiple Mechanisms}

In both the brain and the spinal cord, LY235959 significantly but not completely blocked the c-fos mRNA expression evoked by acute morphine withdrawal. This finding is particularly interesting, since the dose of LY2359559 that we used completely blocked the $c$-fos elevation induced by exogenously applied NMDA. Thus, our data suggest that mechanisms parallel to the NMDA receptor related mechanism may exist in the expression of acute morphine withdrawal. Specifically, in 7-day-old rats, the NMDA receptor plays an important, but not exclusive, role in the expression of acute morphine withdrawal. Other parallel mechanisms may coexist with the NMDA receptor related mechanism. One such possibility is that the AMPA/kainate receptor could play an important role in the expression of acute opiate withdrawal. The AMPA/kainate receptor is colocalized with the NMDA receptor on many cell types (Gu et al. 1996). During ontogeny, AMPA/kainate receptors are known to mediate many cellular functions, such as long term potentiation (LTP) (Jia et al. 1996; Mahanty and Sah 1998), activation of the calmodulin-NOS cascade (Fedele and Raiteri 1999) and phosphorylation of cAMP response element-binding protein (Perkinton et al. 1999), that were thought to be the sole province of the NMDA receptor. Furthermore, several authors have reported that the AMPA/kainate receptor plays an very important, if not the most important, role in the expression of opiate withdrawal even in the adult (Rasmussen 1995; Rasmussen et al. 1996; Kest et al. 1997; McLemore et al. 1997). Thus, multiple and dynamic mechanisms may exist in mediating the acute opiate withdrawal. Further studies to elucidate the dynamic roles of various glutamate receptors in acute opiate withdrawal may prove to be beneficial.

\section{ACKNOWLEDGMENTS}

Supported by NIH (National Institutes of Health) grants DA 01457, DA 00198 and CA 62948 to CEI, and grants DA 06600 and DA 00325 to GAB.

\section{REFERENCES}

Akaike N, Rhee JS (1997): Age-related functional changes of the glutamate receptor channels in rat Meynert neurones. J Physiol 504:665-681 
Bardoni R, Magherini PC, MacDermott AB (1998): NMDA EPSCs at glutamatergic synapses in the spinal cord dorsal horn of the postnatal rat. J Neurosci 18:6558-6567

Barr GA (1992): Behavioral effects of opiates during development. In Miller MW (ed), Development of the central nervous system: effects of alcohol and opiates. WileyLiss, New York, pp 221-254

Barr GA (1993): Reinforcing properties of opiates during early development. In Hammer Jr RP (ed), The Neurobiology of Opiates. Boca Raton, CRC Press, pp 63-83

Barr GA, Zmitrovich A, Hamowy AS, Liu PY, Wang S, Hutchings DE (1998): Neonatal withdrawal following pre- and postnatal exposure to methadone in the rat. Pharmacol Biochem Behav 60:97-104

Bell JA, Beglan CL (1995): Co-treatment with MK-801 potentiates naloxone-precipitated morphine withdrawal in the isolated spinal cord of the neonatal rat. Eur J Pharmacol 294:297-301

Ben-Ari Y, Cherubini E, Krnjevic K (1988): Changes in voltage dependence of NMDA currents during development. Neurosci Lett 94:88-92

Bickel WK, Stitzer ML, Liebson IA, Bigelow GE (1988): Acute physical dependence in man: effects of naloxone after brief morphine exposure. J Pharmacol Exp Ther 244:126-132

Bowe MA, Nadler JV (1990): Developmental increase in the sensitivity to magnesium of NMDA receptors on CA1 hippocampal pyramidal cells. Brain Res Dev Brain Res 56:55-61

Brent PJ, Chahl LA (1993): Enhancement of the opiate withdrawal response by antipsychotic drugs in guinea-pigs is not mediated by sigma binding sites. Eur Neuropsychopharmacol 3:23-32

Cappendijk SL, de Vries R, Dzoljic MR (1993): Excitatory amino acid receptor antagonists and naloxone-precipitated withdrawal syndrome in morphine-dependent mice. Eur Neuropsychopharmacol 3:111-116

Ceger P, Kuhn CM (2000): Opiate withdrawal in the neonatal rat: relationship to duration of treatment and naloxone dose. Psychopharmacology 150:253-259

Curran T, Gordon MB, Rubino KL, Sambucetti LC (1987): Isolation and characterization of the c-fos(rat) cDNA and analysis of post-translational modification in vitro. Oncogene 2:79-84

Dingledine R, Borges K, Bowie D, Traynelis SF (1999): The glutamate receptor ion channels. Pharmacol Rev 51: 7-61

Duman RS, Tallman JF, Nestler EJ (1988): Acute and chronic opiate-regulation of adenylate cyclase in brain: specific effects in locus coeruleus. J Pharmacol Exp Ther 246:1033-1039

Fedele E, Raiteri M (1999): In vivo studies of the cerebral glutamate receptor/NO/cGMP pathway. Prog Neurobiol 58:89-120

Fitzgerald M (1995): Developmental biology of inflammatory pain. Br J Anaesth 75:177-185

Fitzgerald M, Jennings E (1999): The postnatal development of spinal sensory processing. Proc Natl Acad Sci USA 96:7719-7722

Geller LM, Geller EH (1966): A simple technique for the per- manent marking of newborn albino rats. Psychol Rep $18: 221-222$

Gu JG, Albuquerque C, Lee CJ, MacDermott AB (1996): Synaptic strengthening through activation of $\mathrm{Ca} 2+$-permeable AMPA receptors. Nature 381:793-796

Heishman SJ, Stitzer ML, Bigelow GE, Liebson IA (1989a): Acute opioid physical dependence in humans: effect of varying the morphine-naloxone interval. I. J Pharmacol Exp Ther 250:485-491

Heishman SJ, Stitzer ML, Bigelow GE, Liebson IA (1989b): Acute opioid physical dependence in postaddict humans: naloxone dose effects after brief morphine exposure. J Pharmacol Exp Ther 248:127-134

Herman BH, Vocci F, Bridge P (1995): The effects of NMDA receptor antagonists and nitric oxide synthase inhibitors on opioid tolerance and withdrawal. Medication development issues for opiate addiction. Neuropsychopharmacology 13:269-293

Hori Y, Kanda K (1994): Developmental alterations in NMDA receptor-mediated [Ca2+]i elevation in substantia gelatinosa neurons of neonatal rat spinal cord. Brain Res Dev Brain Res 80:141-148

Inturrisi CE (1997): Preclinical evidence for a role of glutamatergic systems in opioid tolerance and dependence. Sem Neurosci 9:110-119

Jia Z, Agopyan N, Miu P, Xiong Z, Henderson J, Gerlai R, Taverna FA, Velumian A, MacDonald J, Carlen P, Abramow-Newerly W, Roder J (1996): Enhanced LTP in mice deficient in the AMPA receptor GluR2. Neuron 17:945-956

Jones KL, Barr GA (1995): Ontogeny of morphine withdrawal in the rat. Behav Neurosci 109:1189-1198

Jones KL, Barr GA (2000): Opiate withdrawal in the fetal rat: a behavioral profile. Pharmacol Biochem Behav 66:419424

Kalb RG, Fox AJ (1997): Synchronized overproduction of AMPA, kainate, and NMDA glutamate receptors during human spinal cord development. J Comp Neurol 384:200-210

Kalb RG, Lidow MS, Halsted MJ, Hockfield S (1992): Nmethyl-D-aspartate receptors are transiently expressed in the developing spinal cord ventral horn. Proc Natl Acad Sci USA 89:8502-8506

Kest B, McLemore G, Kao B, Inturrisi CE (1997): The competitive alpha-amino-3-hydroxy-5-methylisoxazole-4-propionate receptor antagonist LY293558 attenuates and reverses analgesic tolerance to morphine but not to delta or kappa opioids. J Pharmacol Exp Ther 283:12491255

Kirby KC, Stitzer ML, Heishman SJ (1990): Acute opioid physical dependence in humans: effect of varying the morphine-naloxone interval II. J Pharmacol Exp Ther 255:730-737

Mahanty NK, Sah P (1998): Calcium-permeable AMPA receptors mediate long-term potentiation in interneurons in the amygdala. Nature 394:683-687

Mao J (1999): NMDA and opioid receptors: their interactions in antinociception, tolerance and neuroplasticity. Brain Res Brain Res Rev 30:289-304 
Marsh DF, Hatch DJ, Fitzgerald M (1997): Opioid systems and the newborn. Br J Anaesth 79:787-795

Martin WR, Eades CG (1964): A comparison between acute and chronic physical dependence in the chronic spinal dog. J Pharmacol Exp Ther 146:385-394

Mayer DJ, Mao J, Holt J, Price DD (1999): Cellular mechanisms of neuropathic pain, morphine tolerance, and their interactions. Proc Natl Acad Sci USA 96:7731-7736

McLemore GL, Kest B, Inturrisi CE (1997): The effects of LY293558, an AMPA receptor antagonist, on acute and chronic morphine dependence. Brain Res 778:120-126

Morin AM, Hattori H, Wasterlain CG, Thomson D (1989): $[3 \mathrm{H}] \mathrm{MK}-801$ binding sites in neonate rat brain. Brain Res 487:376-379

Morrisett RA, Mott DD, Lewis DV, Wilson WA, Swartzwelder HS (1990): Reduced sensitivity of the Nmethyl-D-aspartate component of synaptic transmission to magnesium in hippocampal slices from immature rats. Brain Res Dev Brain Res 56:257-262

Nestler EJ, Aghajanian GK (1997): Molecular and cellular basis of addiction. Science 278:58-63

Nestler EJ, Tallman JF (1988): Chronic morphine treatment increases cyclic AMP-dependent protein kinase activity in the rat locus coeruleus. Mol Pharmacol 33:127-132

Ozawa S, Kamiya H, Tsuzuki K (1998): Glutamate receptors in the mammalian central nervous system. Prog Neurobiol 54:581-618

Perkinton MS, Sihra TS, Williams RJ (1999): Ca(2+)-permeable AMPA receptors induce phosphorylation of cAMP response element-binding protein through a phosphatidylinositol 3-kinase-dependent stimulation of the mitogen-activated protein kinase signaling cascade in neurons. J Neurosci 19:5861-5874

Rasmussen K (1995): The role of the locus coeruleus and Nmethyl-D-aspartic acid (NMDA) and AMPA receptors in opiate withdrawal. Neuropsychopharmacology 13:295-300

Rasmussen K, Brodsky M, Inturrisi CE (1995): NMDA antagonists and clonidine block c-fos expression during morphine withdrawal. Synapse 20:68-74

Rasmussen K, Fuller RW, Stockton ME, Perry KW, Swinford RM, Ornstein PL (1991): NMDA receptor antagonists suppress behaviors but not norepinephrine turnover or locus coeruleus unit activity induced by opiate withdrawal. Eur J Pharmacol 197:9-16

Rasmussen K, Kendrick WT, Kogan JH, Aghajanian GK (1996): A selective AMPA antagonist, LY293558, suppresses morphine withdrawal-induced activation of locus coeruleus neurons and behavioral signs of morphine withdrawal. Neuropsychopharmacology 15:497505

Represa A, Tremblay E, Ben-Ari Y (1989): Transient increase of NMDA-binding sites in human hippocampus during development. Neurosci Lett 99:61-66

Sharma SK, Klee WA, Nirenberg M (1975): Dual regulation of adenylate cyclase accounts for narcotic dependence and tolerance. Proc Natl Acad Sci USA 72:3092-3096

Sircar R (2000): Developmental maturation of the N-methyl-
D-aspartic acid receptor channel complex in postnatal rat brain. Int J Dev Neurosci 18:121-131

Tanganelli S, Antonelli T, Morari M, Bianchi C, Beani L (1991): Glutamate antagonists prevent morphine withdrawal in mice and guinea pigs. Neurosci Lett 122:270272

Thorat SN, Barjavel MJ, Matwyshyn GA, Bhargava HN (1994): Comparative effects of NG-monomethyl-L-arginine and MK-801 on the abstinence syndrome in morphine-dependent mice. Brain Res 642:153-159

Thornton SR, Smith FL (1997): Characterization of neonatal rat fentanyl tolerance and dependence. J Pharmacol Exp Ther 281:514-521

Thornton SR, Wang AF, Smith FL (1997): Characterization of neonatal rat morphine tolerance and dependence. Eur J Pharmacol 340:161-167

Tremblay E, Roisin MP, Represa A, Charriaut-Marlangue C, Ben-Ari Y (1988): Transient increased density of NMDA binding sites in the developing rat hippocampus. Brain Res 461:393-396

Trujillo KA (1999): Cellular and molecular mechanisms of opioid tolerance and dependence: progress and pitfalls. Pain Forum 8:29-33

Trujillo KA, Akil H (1991a): Inhibition of morphine tolerance and dependence by the NMDA receptor antagonist MK-801. Science 251:85-87

Trujillo KA, Akil H (1991b): Opiate tolerance and dependence: recent findings and synthesis. New Biol 3:915923

Trujillo KA, Akil H (1995): Excitatory amino acids and drugs of abuse: a role for N-methyl-D-aspartate receptors in drug tolerance, sensitization and physical dependence. Drug Alcohol Depend 38:139-154

Windh RT, Little PJ, Kuhn CM (1995): The ontogeny of mu opiate tolerance and dependence in the rat: antinociceptive and biochemical studies. J Pharmacol Exp Ther 273:1361-1374

Zhu H, Barr GA (2000): Naltrexone-precipitated morphine withdrawal in infant rat is attenuated by acute administration of NOS inhibitors but not NMDA receptor antagonists. Psychopharmacology 150:325-336

Zhu H, Barr GA (2001): Inhibition of morphine withdrawal by the NMDA receptor antagonist MK-801 in rat is age dependent. Synapse 40:282-293

Zhu YS, Branch AD, Robertson HD, Huang TH, Franklin SO, Inturrisi CE (1992): Time course of enkephalin mRNA and peptides in cultured rat adrenal medulla. Brain Res Mol Brain Res 12:173-180

Zhu YS, Brodsky M, Franklin SO, Huang T, Inturrisi CE (1993): Metrazole induces the sequential activation of c-fos, proenkephalin, and tyrosine hydroxylase gene expression in the rat adrenal gland: modulation by glucocorticoid and adrenocorticotropic hormone. Mol Pharmacol 44:328-335

Zhu YS, Inturrisi CE (1993): Metrazole induction of c-fos and proenkephalin gene expression in the rat adrenal and hippocampus: pharmacological characterization. Brain Res Mol Brain Res 20:118-124 